\title{
O processo civil no estado constitucional e seus reflexos nas ações de improbidade administrativa*
}

\author{
Civil procedure in a constitutional \\ state and its reflexes in \\ administrative misconduct actions
}

\author{
Luis Renato Vedovato** \\ Thiago Henrique Teles Lopes ${ }^{* *}$
}

* Artigo recebido em 10 de fevereiro de 2018 e aprovado em 16 de abril de 2018. DOI: http://dx.doi.org/10.12660/rda.v278.2019.79031.

** Universidade Estadual de Campinas, Campinas, São Paulo, SP, Brasil. E-mail: 1rvedovato@ gmail.com.

Doutor em direito internacional pela Faculdade de Direito da USP. Professor de direito internacional da Unicamp. Vice-coordenador do Observatório de Direitos Humanos da Unicamp. Pesquisador associado do Observatório das Migrações em São Paulo. Pesquisador do projeto de pesquisa conjunto (Cardiff University e Unicamp) "Examining poverty in a polarised and unequal society: the potential of the Consensual Approach to poverty research in Brazil" - UK Global Challenges Research Fund (GCRF).

*** Universidade Metodista de Piracicaba, Piracicaba, São Paulo, SP, Brasil. E-mail: telesthiago@ hotmail.com.

Juiz de direito em São Paulo. Mestre em direito pela Unimep. Pós-graduado em direito processual civil pela Unisul. 


\section{RESUMO}

O objeto da pesquisa é analisar a estrutura lógica-racional estabelecida na Lei de Improbidade Administrativa, com ênfase na avaliação dos impactos de normas fundamentais, consagradas no novo CPC, na ação de improbidade administrativa, além da aplicabilidade do regime de revelia à ação de improbidade administrativa, o princípio da congruência e a ciência e a manifestação prévia das partes a fim de se evitar decisão surpresa. A Lei de Improbidade Administrativa (Lei no 8.429/1992), entre outros mecanismos legislativos, instituiu um sistema normativo que visa sancionar a prática de condutas ímprobas pelos agentes públicos e terceiros a eles aderentes. Com tal finalidade, essa sistematização criou a ação de improbidade administrativa de natureza cível (entendimento adotado no presente trabalho). Consequentemente, as alterações promovidas no direito processual civil, principalmente em virtude de sua nova fase metodológica (processo civil no Estado Constitucional), que se baseia num modelo cooperativo, trouxeram diversos reflexos nas ações de improbidade administrativa, tanto em seu modelo de constatação para a formação da conviç̧ão judicial quanto em alguns aspectos processuais de igual relevância. O método utilizado é o dedutivo e o procedimento é a investigação bibliográfica e documental, legislativa e jurisprudencial.

\section{PALAVRAS-CHAVE}

Lei de Improbidade Administrativa - processo civil no estado constitucional - modelo cooperativo

\section{ABSTRACT}

The aim of this paper is to analyze the logical-rational structure established in the Administrative Misconduct Law, with emphasis on its procedural model of evidence and the legislative reflexes irradiated. The Act of Administrative Misconduct (n. 8.429/1992), among other legislative mechanisms, established a normative system that aims to punish the practice of misconduct conduct by public agents and third parties. For this purpose, the systematization created the action of administrative misconduct with civil nature (understanding adopted in the present paper). Consequently, the changes promoted in civil procedural law, mainly due to its new methodological phase (civil process in the Constitutional State), which is based on a cooperative model, brought 
several reflexes in the actions of administrative misconduct, both in its model of verification for the judicial conviction, and in some procedural aspects of equal importance. The method used is the deductive and the procedure is the bibliographical and documentary, legislative and judicial decision investigation.

\section{KEYWORDS}

Act of Administrative Misconduct - civil procedure in the constitutional state - cooperative model

\section{Introdução}

Ao contrário dos regimes monárquicos que caminhavam pela absoluta ausência de responsabilidade pessoal do rei ou do imperador, ${ }^{1}$ num sistema constitucional de poderes limitados, a responsabilidade dos agentes estatais caracteriza-se como uma das cláusulas essenciais à configuração do primado da ideia republicana.

Desse modo, a imposição de consequências jurídicas aos agentes públicos em razão da prática de atos ímprobos é ínsita ao regime republicano, tratando-se de uma das mais relevantes decisões políticas fundamentais levadas a efeito pelo constituinte originário, o qual conferiu existência ao princípio da responsabilidade.

Como consequência inarredável do anteriormente evidenciado, a responsabilização dos agentes estatais e dos terceiros a eles aderentes por eventuais atos ímprobos é um efeito correlacionado à República, razão pela qual "o ordenamento jurídico brasileiro conta, é verdade, com vários meios dispostos nos princípios e regras jurídicas que estruturam um arcabouço próprio para a tutela da probidade administrativa", , entre eles, a Lei no 8.429/1992.

Nesse panorama, se faz necessária a observância do devido processo legal previsto em âmbito constitucional (CF/88, art. 5o, LIV) e na Lei de Improbidade Administrativa (art. 17) para a adequada utilização das sanções daí decorrentes.

1 BUENO, José Antonio Pimenta. Direito publico brasileiro e analyse da Constituição do Imperio. Rio de Janeiro: Typographia Imp. e Const. de J. villeneuve \& C., 1857. p. 206, item 267.

2 MARTINS JÚNIOR, Wallace Paiva. Probidade administrativa. 4. ed. São Paulo: Saraiva, 2009. p. 11. 
Lastreado na compreensão de que a natureza jurídica da ação de improbidade administrativa é cível - não obstante a existência de vozes dissonantes a esse respeito - , sua visão epistemológica fia-se ao processo civil no estado constitucional - atual fase metodológica da ciência processual em foco -, cujos efeitos irradiarão em todo o modelo processual inerente à improbidade, notadamente no tocante ao campo probatório daí adveniente.

Nesta seara, as consequências jurídicas impostas em decorrência do reconhecimento da prática de um ato ímprobo são tão ou até mesmo mais graves que aquelas delimitadas pelo direito penal, seja no campo social, seja na esfera estritamente jurídica, como a suspensão dos direitos políticos ou a perda do cargo público em situações que, a depender da gravidade da conduta, não seriam aplicadas na vertente criminal.

Com tal enfoque, mostra-se pertinente aferir, no campo estritamente processual-constitucional, o modelo que deve ser adotado para a incidência do direito sancionador na esfera inerente à ação de improbidade administrativa, tendo em vista as graves implicações que lhe são próprias.

O trabalho, valendo-se do método indutivo, que objetiva chegar a conclusões mais amplas do que o conteúdo fixado pelas premissas em que está fundamentado, tendo como base a pesquisa descritiva e como instrumento procedimental a investigação bibliográfica e documental, legislativa e jurisprudencial do Supremo Tribunal Federal (STF) e do Superior Tribunal de Justiça (STJ), analisa a estrutura lógica-racional estabelecida na Lei de Improbidade Administrativa, com ênfase no seu modelo processual probatório e os reflexos legislativos que lhe foram irradiados.

\section{Da natureza jurídica da ação de improbidade administrativa}

Por força do disposto no artigo 37, §4º da Constituição Federal de 1988, sobreveio a edição da Lei no 8.429/1992 que, entre outras regulamentações inerentes ao tema, disciplina em seus arts. 9o a 11 as modalidades de atos de improbidade administrativa, ao passo que o art. 12 prevê as sanções aplicáveis em decorrência do reconhecimento da prática da conduta ímproba.

É por intermédio da ação de improbidade administrativa preconizada pelo art. 17 da LIA que se busca a responsabilização dos sujeitos ativos das condutas ímprobas que lesaram as entidades delineadas no art. 1o da lei, sujeitando-os às respectivas sanções, como anteriormente delineado. 
Para efeito do presente trabalho, é imprescindível delimitar a natureza jurídica da ação de improbidade administrativa, eis que a partir de então será possível direcionar o modelo processual aplicável.

Em âmbito majoritário, a doutrina entende que ela possui natureza estritamente cível, pois os seus efeitos ostentam caráter nitidamente administrativo e patrimonial e, consequentemente, as penalidades são de caráter civil e político, sem qualquer relação com a seara criminal. ${ }^{3}$

Outra vertente doutrinária, por sua vez - minoritária - , defende a natureza penal da ação de improbidade administrativa, pois a suspensão de direitos políticos e a perda da função pública seriam sanções próprias da seara criminal. ${ }^{4}$

Uma terceira corrente - de viés intermediário - diz que a perda da função pública e a suspensão dos direitos políticos possuem caráter penal, mas o Juízo cível seria o competente para o processamento da ação de improbidade, na medida em que as demais penalidades são de caráter eminentemente cível. ${ }^{5}$

O entendimento do STJ é no sentido de que "a ação de improbidade administrativa tem natureza cível-administrativa, a possibilidade da perda do cargo não a transforma em ação penal". ${ }^{6}$

Não obstante os louváveis argumentos em contrário, entendemos que, ipso facto, a natureza jurídica é extrapenal, até porque o próprio texto constitucional em seu art. $37, \S 4^{\circ}$, estabelece que os atos de improbidade administrativa importarão na suspensão dos direitos políticos, a perda da função pública, a indisponibilidade de bens e o ressarcimento ao erário, sem prejuízo da ação penal cabível.

3 FERRAZ, Sergio. Aspectos processuais na lei sobre improbidade administrativa. In: BUENO, Cassio Scarpinella; PORTO FILHO, Pedro Paulo de Resende (Org.). Improbidade administrativa: questões polêmicas e atuais. São Paulo: Sociedade Brasileira de Direito Público, 2001. p. 364-386.

4 TOJAL, Sebastião Botto de Barros; CAETANO, Flávio Crocce. Competência e prerrogativa de foro em ação civil de improbidade administrativa. In: Cassio Scarpinella Bueno e Pedro Paulo de Resende Porto Filho (Org.), Improbidade administrativa, op. cit., p. 350-363.

5 ALVARENGA, Aristides Junqueira. Reflexões sobre improbidade administrativa no direito brasileiro. In: Cassio Scarpinella Bueno e Pedro Paulo de Resende Porto Filho (Org.), Improbidade administrativa, op. cit., p. 86-92.

6 SUPERIOR TRIBUNAL DE JUSTIÇA. Corte Especial, AgRg na Rcl 10.037 - MT, rel. min. Luis Felipe Salomão, DJe 25/11/2015. Disponível em: <ww2.stj.jus.br/processo/revista/documento/ mediado/?componente=ATC\&sequencial $=54894933 \&$ num_registro $=201202010299 \&$ data $=2015$ 1125\&tipo=5\&formato=PDF $>$. Acesso em: 5 out. 2017. 
Ora, se a natureza jurídica fosse criminal, não haveria sentido na expressão "sem prejuízo da ação penal cabível" incluída ao final do dispositivo constitucional citado.

Em idêntico posicionamento, o STF pacificou a celeuma e, por seu turno, adotou a vertente doutrinária majoritária ao entender que os agentes políticos, excluído o presidente da República, se submetem integralmente ao regime de responsabilização decorrente da improbidade administrativa, afastando o foro especial por prerrogativa de função exatamente diante da natureza civil da improbidade ${ }^{7}$.

\section{O processo civil no estado constitucional}

Apurada a natureza jurídica cível da ação de improbidade administrativa, por certo, aplicável o direito processual civil nas relações jurídico-processuais daí advenientes. Consequentemente, torna-se impositivo trilhar por esse hidratado vértice do direito.

Na dicção de Miguel Reale, ${ }^{8}$ o direito é fruto de uma vertente cultural que se correlaciona axiologicamente com cada momento histórico vivenciado pelo homem, ou seja, o vínculo jurídico estaria atrelado ao processo de escolha, entre os diversos caminhos possíveis, levado a efeito pela sociedade decorrente dos valores de convivência adotados em cada período.

O autor também descreve "a sociedade como condição do Direito, a Justiça como fim último, a bilateralidade atributiva como forma de ordenatória específica, e o Poder como garantia de sua atualização". ${ }^{9}$

Destarte, o processo civil, como ramo autônomo do direito, embora seja eminentemente técnico, possui sua acepção oriunda dos fatores culturais aceitos em cada época, surgindo o que a doutrina processual denomina de fases metodológicas do direito processual civil.

Por essa razão, a evolução histórica do direito processual é normalmente segmentada em três fases metodológicas: a) praxismo ou sincretismo (período em que o direito processual e o material não eram distintos); b) processualismo

7 SUPREMO TRIBUNAL FEDERAL. Pleno, Petição noㅜ 3240 AgR/DF, rel. min. Roberto Barroso. Disponível em: <www.stf.jus.br>. Acesso em: 26 mar. 2019.

8 REALE, Miguel. Filosofia do direito. 20. ed. São Paulo: Saraiva, 2012. p. 702-703.

$9 \quad$ Ibid., p. 703. 
(época marcada pela cientificidade do processo e, portanto, com nítidas diferenciações com relação ao direito material); e c) instrumentalismo (momento histórico intermediário entre o caráter autônomo do direito processual e sua necessidade de efetividade no plano material). ${ }^{10}$

Na atualidade, entretanto, já se propala a existência de uma quarta fase metodológica do direito processual que, arvorando-se no conceito adotado por Daniel Mitidiero, denominamos de processo civil no estado constitucional, ${ }^{11}$ não obstante a existência de outras denominações como neoprocessualismo ${ }^{12}$ que remete o estudioso ao neoconstitucionalismo.

As premissas metodológicas do novo modelo atinente ao direito processual civil foram amplamente capitaneadas pelo novo Código de Processo Civil, notadamente em virtude de sua visão colaborativa.

Entre diversas outras modificações, a novel legislação impôs a observância obrigatória aos preceitos constitucionais (CPC, art. $1^{\circ}$ ), o direito à obtenção a solução de mérito em tempo razoável (CPC, art. $\left.4^{\circ}\right)$, a boa-fé objetiva como padrão de conduta de todos os sujeitos processuais (CPC, art. 5), o direito a prolação de uma decisão justa e premida de ampla colaboração e participação das partes (CPC, art. $\left.6^{\circ}\right)$, tratamento igualitário atribuído a todos os sujeitos processuais (CPC, art. $\left.7^{\circ}\right)$, bem como o impedimento a prolação de decisão pela qual as partes não tiveram a oportunidade prévia de manifestação sobre os seus fundamentos (CPC, arts. 9o e 10).

Esse "modelo cooperativo parte da ideia que o Estado tem como dever primordial propiciar condições para a organização de uma sociedade livre, justa e solidária (art. 3o, I, da $\mathrm{CF} / 88$ ), fundado que está na dignidade da pessoa humana (art. 1을 III, da $\mathrm{CF} / 88){ }^{\prime \prime} \cdot{ }^{13} \mathrm{E}$, para tanto, o juiz deve ser paritário no diálogo e assimétrico quando da prolação da decisão que deverá ser necessariamente justa e efetiva.

Finalizando a ideia do até então exposto acerca da nova concepção do direito processual, Daniel Mitidiero expõe

10 DIDIER JUNIOR, Fredie. Curso de direito processual civil: introdução ao direito processual civil, parte geral e processo de conhecimento. 20. ed. Salvador: Jus Podivm, 2018. v. 1, p. 45.

11 MITIDIERO, Daniel. Colaboração no processo civil: pressupostos sociais, lógicos e éticos. 3. ed. São Paulo: Revista dos Tribunais, 2015. p. 48.

12 CAMBI, Eduardo. Neoconstitucionalismo e neoprocessualismo - direitos fundamentais, políticas públicas e protagonismo Judiciário. São Paulo: Almedina, 2016. p. 125; Fredie Didier Junior, Curso de direito processual civil, op. cit., p. 45-46.

13 Daniel Mitidiero, Colaboração no Processo Civil, op. cit., p. 98. 
A condução do processo civil a partir daí é gravada por deveres cooperativos - esclarecimento, diálogo, prevenção e auxílio. A boa-fé subjetiva e objetiva tem que ser observada por todos os seus participantes (art. 5o do CPC/2015). A verdade provável é um objetivo cujo alcance permite a prolação de decisões justas (arts. 300 e 369 do CPC/2015), sendo, portanto, tarefa conjunta do juiz e das partes (arts. 369 e 370 do CPC/2015), na medida de seus interesses persegui-la. ${ }^{14}$

Esse novo standard traz inegáveis consequências a todo o universo de demandas intentadas perante o Poder Judiciário, com especial relevo à improbidade administrativa, conforme reflexos adiante aduzidos.

\section{O modelo processual no estado constitucional e sua irradiação para as ações de improbidade administrativa}

Tal como apontado linhas atrás, sendo o direito resultado de um processo cultural, a Constituição da República Federativa do Brasil de 1988 - que constitui o ápice do sistema piramidal das normas - estabelece a plena observância ao princípio democrático em virtude da adoção da soberania popular $(\mathrm{CF} / 88$ art. 1ㅇ, caput, e seu parágrafo único) como o pilar que une o estado de direito e um estado democrático. Assim, o modelo processual se irradia para as ações de improbidade, exigindo a aplicação das garantias estabelecidas na Constituição Federal.

Nesse prisma, bem explica José Joaquim Gomes Canotilho:

Só o princípio da soberania popular segundo o qual "todo o poder emana do povo" assegura e garante o direito à igual participação na formação democrática da vontade popular. Assim, o princípio da soberania popular concretizado segundo procedimentos juridicamente regulados serve de "charneira" entre o "Estado de direito" e o "Estado democrático" possibilitando a compreensão da moderna fórmula Estado de direito democrático. ${ }^{15}$

14 Ibid.

15 CANOTILHO, José Joaquim Gomes. Direito constitucional e teoria da constituição. 6. ed. Coimbra: Almedina, 2002. p. 100. 
Não é por outra razão que a construção de uma sociedade livre, justa e solidária $(\mathrm{CF} / 88$, art. 3o, inciso I) como fundamento da República torna consequência inarredável que o processo judicial se destine a construção verdadeira dos fatos, cujo escopo, nesse particular, é derivado da atuação do estado-juiz.

A esse respeito, leciona o doutrinador italiano Michele Taruffo:

A administração da justiça constitui um setor importantíssimo da vida social e da atividade do Estado; desse modo, nessa dever-se-iam encontrar os próprios valores de verdade que constituem os critérios constitutivos do correto funcionamento do sistema sociopolítico. Seria, por assim dizer, um tanto paradoxal um sistema democrático, inspirado no valor da verdade, no qual, entretanto, a administração da justiça não se inspirasse em tal valor, ou mesmo que se fundasse sistematicamente no erro, na mentira ou na distorção da verdade. ${ }^{16}$

Inspirado nesse paradigma, não se pode perder de vista a necessidade de contornos processuais que atendam ao intento democrático oriundo dos valores sociais atualmente estabelecidos pela Constituição Federal, em especial quando a potencialidade consequencial daí oriunda possa resultar em sanções aptas a grave supressão de direitos, como, aliás, bem arregimentado por Néviton Guedes:

Quando o Estado desenvolve suas funções, também se constitui em verdadeiro interesse público a mais ampla garantia e proteção dos interesses individuais dos particulares eventualmente atingidos por sua ação, em razão, precisamente, do especial lugar que a Constituição dedicou aos direitos e garantias fundamentais. Obviamente, a preocupação do Estado com os direitos e garantias do cidadão tem especial relevância quando se cuida de processos em que se lhes possa resultar alguma espécie de imposição de sanção consistente em sacrifícios de seus direitos de liberdade e de patrimônio, como é, em especial medida, o caso da ação civil pública de improbidade. ${ }^{17}$

16 TARUFFO, Michele. Uma simples verdade: o juiz e a construção dos fatos. Tradução de Vitor de Paula Ramos. São Paulo: Marcial Pons, 2016. p. 120-121.

17 GUEDES, Néviton. Improbidade administrativa: temas atuais e controvertidos. Coordenação do ministro Mauro Campbell Marques. Rio de Janeiro: Forense, 2017. p. 287-288. 
É inegável, pois, que a Lei de Improbidade Administrativa constitui um importante marco na luta contra a prática de atos de corrupção e de tergiversação do patrimônio público. Tal normatividade é um importante mecanismo que visa tutelar, inclusive, a higidez do sistema democrático. Nesse ponto, merece destaque a obra de Carlos Alberto Alvaro de Oliveira, concernente ao formalismo no processo civil. ${ }^{18}$

A legitimidade do estado democrático de direito está necessariamente atrelada ao funcionamento lícito e moral das instituições, não sendo suficiente uma democracia meramente formal, até porque o povo possui direito a governo honesto, eficiente e zeloso, razão pela qual a democracia efetiva pressupõe a probidade administrativa como um elemento essencial. ${ }^{19}$

Todavia, muito embora a conduta proba dos agentes públicos seja imprescindível para a configuração de uma efetiva democracia, esta última também exige a observância integral de todos os princípios que lhe regem, entre eles, o do devido processo legal e o da ampla defesa, principalmente nas searas sancionatórias, pois a imperatividade estatal também deve ser subserviente ao ordenamento jurídico, ao menos em um estado democrático.

Sobre a questão, Fernando Capez descreve com bastante propriedade o seguinte:

Não se pode, contudo, transformar-se, sob o pálio da defesa social, em aparato bélico repressivo que avilte a dignidade do imputado, destruindo sua imagem e honra, subvertendo seu patrimônio, sem qualquer preocupação em analisar o conteúdo ontológico, os requisitos subjetivos ou a tipicidade material do ato acoimado de ímprobo.

Independente de sua natureza jurídica, questão de menor relevância, a gravidade de suas sanções faz com que Lei de Improbidade Administrativa tenha que se submeter aos mesmos princípios constitucionais garantidores da dignidade da pessoa humana que os fatos pertencentes à esfera penal..$^{20}$

18 OLIVEIRA, Carlos Alberto Alvaro de. Do formalismo no processo civil: proposta de um formalismo-valorativo. 4. ed. rev. atual. e aum. São Paulo: Saraiva, 2010. p. 35.

19 ZAVASCKI, Teori Albino. Processo coletivo: tutela de direitos coletivos e tutela coletiva de direitos. 7. ed. São Paulo: Revista dos Tribunais, 2017. p. 100.

20 CAPEZ, Fernando. Improbidade administrativa: limites constitucionais. 2. ed. São Paulo: Saraiva, 2015. p. 340. 
A inexistência de disponibilidade concernente às questões envolvidas nas ações de improbidade administrativa reveste-se de uma dupla feição. A primeira envolvendo a indisponibilidade do próprio direito material discutido (probidade) e a segunda, igualmente, concernente à idêntica impossibilidade de disposição da utilização do processo judicial adequado e, por consectário, necessariamente voltado à prolação de uma decisão de mérito justa e efetiva com plena participação efetiva das partes (CPC, art. $6^{\circ}$ ).

Num estado verdadeiramente democrático, o pleno exercício do direito de defesa é tão relevante quanto a imposição de inderrogável sancionamento ao agente público que lesa a probidade administrativa em qualquer de suas facetas. Em outras palavras, o Estado que pune deve ser o mesmo que zela por um processo justo e efetivo, dentro dos parâmetros constitucionais e legais. A ampla defesa é, igualmente, um direito indisponível da sociedade, tal como o é o zelo pela coisa pública.

O Superior Tribunal de Justiça já trilhou em sentido análogo ao anteriormente evidenciado. Senão, vejamos:

Esta circunstância é de extrema relevância em demandas como a sub examine, em que se discute a prática de ato de improbidade administrativa. Isso porque, embora tenha um caráter eminentemente cível, é inegável o caráter sancionatório da demanda, tendo em vista as sanções aplicáveis - que implicam, inclusive, na suspensão transitória de direitos políticos - , e, ainda, a eventual irradiação dos seus efeitos para outras esferas, tais como, na administrativa e no penal. Assim, não só por se tratar de direitos indisponíveis, mas - e ainda o que é mais relevante - tendo em vista a natureza dos interesses envolvidos, sobreleva ainda mais a importância de se garantir exercício do direito de defesa ao requerido a fim de que o sistema de justiça possa prolatar uma resposta à sociedade que efetivamente proteja os interesses públicos envolvidos. ${ }^{21}$

O princípio democrático, consagrado na Constituição Federal, lastreou-se, entre outros ramos, para as diretrizes processuais e, como consectário

21 SUPERIOR TRIBUNAL DE JUSTIÇA. Segunda Turma, REsp 1.330.058-PR, rel. min. Mauro Campbell Marques, Dje 28/6/2013. Disponível em: <ww2.stj.jus.br/processo/revista/ documento/mediado/?componente=ATC\&sequencial=29607567\&num_registro=20 1201286385\&data $=20130628 \&$ tipo $=5 \&$ formato=PDF $>$. Acesso em: 31 ago. 2017. 
desses reflexos, o processo deixou de ser um direito disponível das partes nele inseridas e passou a integrar uma seara de indisponibilidade do indivíduo-cidadão, em especial diante de um contexto social em que a imperatividade estatal, notadamente no enfoque jurisdicional, observa a colaboração de todos os envolvidos para a ulterior confecção de uma decisão justa (processo civil no Estado Constitucional).

Assim, como corolário do direito a um processo justo (CF/88, art. 5o, LIV), a plena participação das partes durante a tramitação processual com inequívoca possibilidade de influência sobre a convicção do estado-juiz - fiscalizando a racionalidade da jurisdição - é exercida tanto pelo autor quanto pelo réu, em observância ao contraditório ( $\mathrm{CF} / 88$, art. 5o, LV), impondo, com certos limites, amplo direito a produção de provas e uso dos recursos em geral, ${ }^{22}$ principalmente nas ações de improbidade administrativa em razão das graves sanções que lhe são inerentes.

Não é por outro motivo que o processo ganhou uma dimensão epistêmica, tal como defendido por Michele Taruffo:

O processo, na verdade, é também um "lugar" em que normas são aplicadas, valores são postos em prática, garantias são asseguradas, direitos são reconhecidos, interesses são tutelados, escolhas econômicas são feitas, problemas sociais são enfrentados, recursos são alocados, o destino das pessoas é determinado, a liberdade dos indivíduos é tutelada, a autoridade do Estado é manifestada... e controvérsias são resolvidas através de decisões pretensamente justas. ${ }^{23}$

Dentro desse contexto social que contemporaneamente resultou na formação de um processo civil de natureza Constitucional, conforme abordado linhas atrás, muito semelhante ao que deve ser trilhado no âmbito penal, a ação de improbidade administrativa deve tramitar rigorosamente em busca da prolação de uma decisão de mérito justa e efetiva.

Isso porque, entre outras razões, o agente estatal, em regra, cuidadosamente escolhido pela sociedade - que, inclusive, empreende grandes investimentos em sua formação - , não deveria ser sancionado por condutas

22 MITIDIERO, Daniel; MARINONI, Luiz Guilherme; ARENHART, Sérgio Cruz Arenhart. Novo curso de processo civil. Teoria do processo civil, v. 1. São Paulo: Revista dos Tribunais, 2015. p. 310-311.

23 Ibid., p. 160. 
tidas como ímprobas sem que o resultado daí adveniente tenha sido calcado num processo epistêmico.

Com tal percepção, é oportuno considerar o reforço argumentativo em relação à latente necessidade da busca da verdade dos fatos com ampla dilação probatória (CPC, art. 369), inclusive de ofício pelo estado-juiz (CPC, art. 370) nos feitos que apuram a improbidade administrativa, visando evitar, com maior robustez, a prolação de uma decisão baseada em presunções processuais - como modelo ideológico escolhido - que ostentam um condão mais propício a um resultado injusto.

É, em tal norte ideológico-legislativo, que deve caminhar todo processo judicial, notadamente aqueles que envolvam a probidade administrativa, tendo em vista as fortes consequências sancionatórias preconizadas pelo ordenamento jurídico para tanto, até porque tais efeitos penalizadores acarretam em legítima suspensão de direitos fundamentais e patrimoniais dos responsáveis.

Ainda nesse contexto, apesar de a opção legislativa para fins de tipicidade dos atos de improbidade administrativa ter se dado, em regra, com a utilização de tipos abertos calcados em conceitos jurídicos indeterminados (arts. 9o, 10 e 11), exceto em relação ao novo art. 10-A da LIA, exatamente para possibilitar uma equidade cíclica, essa subsunção acarreta uma enorme responsabilidade valorativa do intérprete. ${ }^{24}$

Tal acepção, como aludido pelo ministro Dias Toffoli no Recurso Extraordinário no 656.558-SP, foi bem resumida da seguinte maneira:

o que não se pode admitir, sob a óptica constitucional, é que os tipos abertos, instituídos após a promulgação da Constituição Federal de 1988, originalmente previstos para evitar o engessamento da Lei no 8.429/92, afastem da vida pública ou punam indevidamente aqueles que agem de boa-fé. ${ }^{25}$

Ora, num ambiente republicano baseado no princípio democrático que irradia efeitos destinados à adoção de um processo judicial que conduza a

GARCIA, Emerson; ALVES, Rogério Pacheco. Improbidade administrativa. 9. ed. São Paulo: Saraiva, 2017. p. 364-370.

25 SUPREMO TRIBUNAL FEDERAL. Segunda Turma, RE 656.558-SP, rel. min. Dias Toffoli. Disponível em: <www.stf.jus.br/arquivo/cms/noticiaNoticiaStf/anexo/RE656558DT.pdf>. Acesso em: 31 ago. 2017. 
um resultado justo e efetivo (epistêmico), não se autoriza, como consectário lógico interpretativo, a responsabilização de qualquer agente estatal com base em valorações que destoem do sentido normativo constitucional da Lei de Improbidade Administrativa.

É, por assim dizer, que além da presunção de boa-fé ínsita a todos os atos administrativos, principalmente quando legítimos e devidamente fundados em razões de fato que possam justificar a opção escolhida, a conclusão pela prática de uma conduta ímproba pressupõe a concomitância da presença do dolo ou da culpa - esta última somente para o artigo 10 da LIA - e a inobservância dos padrões de conduta coibidos pela Lei no 8.429/1992.

Vale asseverar que a democracia exige, por parte dos agentes públicos, a eleição cotidiana de escolhas diretivas para a função estatal exercida. No entanto, nem sempre a adoção de uma direção lastreada na boa-fé e que ulteriormente se verificou não ser a mais adequada pode - necessariamente resultar em violação a probidade administrativa, sob pena de tornar inviável a função administrativa. Não se sanciona, por óbvio, a mera incompetência ou irregularidade quando inexistente a má-fé.

A esse respeito, tem sido o posicionamento do Superior Tribunal de Justiça:

Assim, para a correta fundamentação da condenação por improbidade administrativa, é imprescindível, além da subsunção do fato à norma, caracterizar a presença do elemento subjetivo. A razão para tanto é que a Lei de Improbidade Administrativa não visa punir o inábil, mas sim o desonesto, o corrupto, aquele desprovido de lealdade e boa-fé. ${ }^{26}$

Desse modo, apesar da natureza cível atinente à ação de improbidade administrativa e suas respectivas sanções, como bem exposto por Emerson Garcia e Rogério Pacheco Alves, cotidianamente haverá a aplicação dos princípios incidentes ao direito penal, haja vista seu mais aprofundado rigorismo na ampliação concernente a outorga de garantias fundamentais ao

26 SUPERIOR TRIBUNAL DE JUSTIÇA. Segunda Turma, REsp n. 1.660.398-PE, rel. min. Herman Benjamin, Dje 30/6/2017. Disponível em: <ww2.stj.jus.br/processo/revista/documento/ mediado/?componente $=$ ATC\&sequencial $=72535497 \&$ num_registro $=201700202678$ $\&$ data $=20170630 \&$ tipo $=5 \&$ formato=PDF $>$. Acesso em: 31 ago. 2017. 
cidadão-processado. ${ }^{27}$ Dessa forma, defende-se a natureza cível dessa ação, porém, é inevitável que as garantias do processo sejam utilizadas.

Como, inegavelmente, toda decisão judicial ostenta graus de alcance da verdade, muito embora, como já dito anteriormente, aquela - a verdade real - deva ser o norte principal do processo civil no estado constitucional, nem sempre será possível alcançá-la, tornando-se, por vezes, um objetivo inatingível.

Nessa trilha, é possível evidenciar a existência de três modelos de constatação com a finalidade de pautar critérios sobre a análise dos fatos pelo estado-juiz, observado, é claro, o prévio contraditório, os quais foram muito bem reverberados por Danilo Kunijnik:

De forma geral, existem dois modelos de constatações fundamentais extremos, dos quais se pode partir e aos quais se agrega um terceiro, de natureza intermediária, formando-se uma estrutura de três modelos, quais sejam, o juízo de fato formado a partir de uma preponderância de provas, de uma prova clara e convincente (intermediário) e de uma prova além da dúvida razoável.

Em ordem decrescente de grau probabilístico, o primeiro consiste na chamada "prova além da dúvida razoável". É o que vigora no processo penal. Em outro extremo está a "preponderância das provas", empregado, via de regra, no processo civil. ${ }^{28}$

Por essa razão, o modelo de constatação dos feitos judiciais referentes à improbidade administrativa (procedimento probatório) não deverá seguir o standard próprio da ótica cível e nem necessariamente aquele inerente à vertente penal, mas sim um modelo misto, no qual, "embora estejam a superar aqueles necessários à formação da convicção para a condenação civil, se encontram aquém daqueles suficientes para determinar a condenação penal".$^{29}$

Convém mencionar, nesse ponto, que muito embora tradicionalmente tem sido permitida a utilização do modelo denominado "preponderância das

27 Emerson Garcia e Rogério Pacheco Alves, Improbidade administrativa, op. cit., p. 624.

28 KNIJNIK, Danilo. A prova nos juízos cível, penal e tributário. Rio de Janeiro: Forense, 2007. p. 37.

29 CARPES, Artur. O direito fundamental ao processo justo: notas sobre o modelo de constatação nos processos envolvendo as Ações de Improbidade Administrativa. In: LUCON, Paulo Henrique dos Santos; COSTA, Eduardo José da Fonseca; COSTA, Guilherme Recena (Coord.). Improbidade administrativa: aspectos processuais da Lei ํㅡㄹ 8.429/92. São Paulo: Atlas, 2004. p. $56-57$. 
provas" para a esfera atinente aos processos cíveis, tal proceder somente pode ser pregado quando a controvérsia gravita em torno de litígios que versem apenas sobre o patrimônio.

Em sentido contrário, como dito, quando o processo civil gira em torno de matérias cujos efeitos possam extrapolar a esfera patrimonial, o critério utilizado deve ser, no mínimo, o intermediário ("prova clara e convincente"), como no caso das ações de improbidade administrativa. ${ }^{30}$

Nessa ótica, aduz Artur Carpes:

pode-se afirmar que a justiça a ser buscada nos processos envolvendo ações de improbidade administrativa irá depender da conformação do procedimento para que, no que se refere ao convencimento do órgão judicial quanto aos fatos, sua constatação esteja baseada no modelo intermediário da "prova clara e convincente", e não da mera "preponderância de prova", standard próprio dos casos meramente civis, ou da "prova acima da dúvida razoável", modelo característico dos processos penais. ${ }^{31}$

Embora o tema não tenha ainda sido objeto de grande apelo em âmbito jurisprudencial, é possível observar que o STJ, por via oblíqua, já caminhou pela adoção do modelo intermediário de constatação ("prova clara e convincente"); senão vejamos:

3. No caso, inexiste prova inequívoca de prejuízo ao Erário, razão pela qual não há como sustentar a condenação dos recorrentes com suporte no art. 10, VIII, da Lei de Improbidade Administrativa. 4. Houve, contudo, prática de ato de improbidade que atenta contra os princípios da Administração Pública, na medida que, de acordo com o arcabouço fático delineado pelas instâncias de origem, restou claramente evidenciado o dolo, no mínimo genérico, dos recorrentes em viabilizar, indevidamente, a contratação direta de serviço de elaboração de estudos técnicos preliminares para a implantação de trem de alta velocidade (trem-bala) entre Brasília/DF e Goiânia/GO..$^{32}$ [grifamos]

30 Danilo Knijnik, A prova nos juízos cível, penal e tributário, op. cit., p. 38-39.

Artur Carpes, O direito fundamental ao processo justo, op. cit., p. 57.

32 SUPERIOR TRIBUNAL DE JUSTIÇA. Primeira Turma, REsp n. 1.470.675/DF, rel. para o Acórdão min. Sérgio Kukina, DJe 9/2/2017. Disponível em: <ww2.stj.jus.br/processo/revista/ 
De todo modo, ainda que haja inclinação pela utilização, ao menos, do padrão de constatação intermediário no âmbito das ações de improbidade administrativa, com fulcro no modelo cooperativo atualmente vigente para o direito processual civil, espera-se que a "decisão judicial enuncie, fundamentalmente, o modelo de constatação de que se vale para formar o juízo de fato [...] viabilizando que esse critério seja conhecido, justificado e, obviamente, submetido ao contraditório enquanto capítulo essencial do julgamento" ${ }^{33}$

\section{Outros marcos atinentes à apuração dos atos de improbidade administrativa do processo civil no estado constitucional}

Apesar da inviabilidade de se retratar, neste estudo, todas as particularidades processuais inerentes às ações de improbidade administrativa, é possível perceber algumas significativas diferenças procedimentais quando comparado ao procedimento comum preconizado no Título I do Livro I da parte especial do novo Código de Processo Civil.

Tais particularidades, aliás, somente corroboram as afirmações levantadas no tópico anterior deste trabalho, haja vista as diferenças umbilicais que envolvem as ações de improbidade e outras de natureza cível cuja controvérsia gire em torno de questões e interesses meramente patrimoniais.

O artigo 17, §7으, da Lei no 8.429/1992 dispõe que "Estando a inicial em devida forma, o juiz mandará autuá-la e ordenará a notificação do requerido, para oferecer manifestação por escrito, que poderá ser instruída com documentos e justificações, dentro do prazo de quinze dias" ${ }^{34}$

Muito embora "a ratio essendi do $\$ 70$ do art. 17 da Lei 8.429/1992 é a de evitar o nascimento de uma ação de improbidade temerária, destituída de base razoável, em prol da honorabilidade da administração e do agente público acusado da prática de ato ímprobo" ${ }^{35}$ torna-se indene de dúvidas

documento/mediado/?componente=ATC\&sequencial=68022110\&num_registro $=20130398084$ $2 \&$ data $=20170209 \&$ tipo=5\&formato=PDF $>$. Acesso em: 16 out. 2017.

33 Danilo Knijnik, A prova nos juízos cível, penal e tributário, op. cit., p. 45.

34 BRASIL. Lei n $n^{0} 8.429$ de 2 de junho de 1992. Disponível em: <www.planalto.gov.br/ccivil_03/leis/ L8429.htm>. Acesso em: 9 out. 2017.

35 SUPERIOR TRIBUNAL DE JUSTIÇA. Segunda Turma, REsp n. 1.124.919 - SP, rel. ministro Humberto Martins, Dje 5/10/2009. Disponível em: <ww2.stj.jus.br/processo/revista/ documento/mediado/?componente=ATC\&sequencial=6277616\&num_registro=200 900333870\&data=20091005\&tipo=5\&formato=PDF $>$. Acesso em: 31 ago. 2017. 
que tal comando normativo origina-se do princípio democrático de índole constitucional, principalmente quando ponderados os enormes impactos negativos que um processo dessa natureza causa a qualquer cidadão, notadamente a um agente público que poderá, ulteriormente, ser inocentado.

Assim, não obstante a existência de vozes dissonantes, ${ }^{36}$ inclusive de forma prevalecente no âmbito do STJ, no sentido da prescindibilidade dessa fase preliminar por se tratar de mera nulidade relativa, ${ }^{37}$ "violar esse regime processual singular é violar a garantia da ampla defesa (art. 5o, LV, CF)" ${ }^{\prime 38}$ e, portanto, se trata de vício insanável amoldando-se a uma hipótese de nulidade absoluta.

Portanto, é próprio do procedimento previsto na Lei de Improbidade Administrativa que haja o controle prévio para fins de recebimento da petição inicial, como forma de evitar lides temerárias. Tal modus operandi não se trata de um mero detalhe, mas sim de uma garantia inarredável do processo civil com fundamento no estado constitucional, cujo descumprimento não pode ser caracterizado como nulidade relativa e, de consequência, sanável.

Outro ponto sensível concernente ao modelo de apuração inerente às ações de improbidade administrativa reside na possibilidade ou não de incidência dos efeitos da revelia, cuja conceituação abaixo transcrevo:

Revelia. É a ausência de contestação. Caracteriza-se quando o réu: a) deixa transcorrer em branco o prazo para a contestação; b) contesta intempestivamente; c) contesta formalmente, mas não impugna os fatos narrados pelo autor na petição inicial. A revelia pode ser total ou parcial, formal ou substancial. Há revelia parcial quando o réu deixa de impugnar algum ou alguns dos fatos articulados pelo autor na vestibular. Há revelia formal quando não há formalmente a peça de contestação ou quando é apresentada intempestivamente. Há revelia

36 NEVES, Daniel Amorim Assunção; OLIVEIRA, Rafael Carvalho Rezende. Manual de improbidade administrativa. 5. ed. rev., atual. e ampl. Rio de Janeiro: Forense; São Paulo: Método, 2017. p. 210-212.

37 SUPERIOR TRIBUNAL DE JUSTIÇA. Segunda Turma, Recurso Especial nº 1.319.770-SP, rel. ministro Herman Benjamin, Dje 10/4/2017. Disponível em: <ww2.stj.jus.br/processo/ revista/documento/mediado/?componente=ATC\&sequencial $=35971972 \&$ num_regi stro=201200049192\&data $=20170419 \&$ tipo $=5 \&$ formato=PDF $>$. Acesso em: 31 ago. 2017.

38 PAZZAGLINI FILHO, Marino. Lei de Improbidade Administrativa comentada: aspectos constitucionais, administrativos, civis, criminais, processuais e de responsabilidade fiscal, legislação e jurisprudência. 6. ed. São Paulo: Atlas, 2015. p. 207. 
substancial quando, apesar de o réu ter apresentado a peça, não há conteúdo de contestação, como, por exemplo, quando o réu contesta genericamente, infringindo o CPC 336 caput. $^{39}$

Como se vê, um dos efeitos substanciais da revelia insere-se na presunção de veracidade dos fatos alegados na petição inicial (CPC, art. 344), o que permite, inclusive, a depender do caso, que o estado-juiz proceda ao julgamento antecipado da demanda (CPC, art. 355, inciso II).

Há decisões do STJ no sentido de ser possível a revelia nos feitos concernentes à improbidade administrativa; senão vejamos:

3. Inexiste nulidade por cerceamento de defesa se réu queda-se silente diante das oportunidades para se manifestar: notificação para apresentação de defesa prévia (art. 17 da LIA), citação para contestar e intimação para especificação de provas. Operação dos efeitos da revelia previstos no art. 322 do CPC. ${ }^{40}$

Todavia, também existem precedentes em sentido contrário emanados pela mesma Corte Superior de Justiça a respeito do tema, sob o enfoque de que os direitos tratados nas ações de improbidade administrativa são indisponíveis e, portanto, inaplicável a presunção de veracidade dos fatos alegados na petição inicial, especialmente porque, apesar da natureza cível, as graves sanções previstas em lei acarretam efeitos irradiantes para outras esferas, como a administrativa e penal. ${ }^{41}$

José Antonio Remedio, ao tratar da natureza jurídica do bem protegido, assevera que "o interesse público existente na tutela da probidade administrativa identifica-se como interesse difuso". ${ }^{42}$

39 NERY JUNIOR, Nelson; ANDRADE NERY, Rosa Maria. Comentários ao Código de Processo Civil. São Paulo: Revista dos Tribunais, 2015. p. 958.

40 SUPERIOR TRIBUNAL DE JUSTIÇA. Segunda Turma, EDcl no AREsp n. 57435-RN, rela mina Eliana Calmon, DJe 9/10/2013. Disponível em: <ww2.stj.jus.br/processo/revista/ documento/mediado/?componente=ATC\&sequencial=31386412\&num_registro=20 $1102260649 \&$ data $=20131009 \&$ tipo $=5 \&$ formato=PDF $>$. Acesso em: 17 out. 2017.

${ }^{41}$ SUPERIOR TRIBUNAL DE JUSTIÇA. Segunda Turma, REsp n. 1.330.058-PR, rel. min. Mauro Campbell Marques, DJe 28/6/2013. Disponível em: <ww2.stj.jus.br/processo/revista/ documento/mediado/?componente=ATC\&sequencial $=29607567 \&$ num_registro $=20$ 1201286385\&data=20130628\&tipo=5\&formato=PDF $>$. Acesso em: 17 out. 2017.

42 REMEDIO, José Antonio. Direito administrativo. 2. ed. São Paulo: Verbatim, 2015. p. 741. 
Traçadas as diretrizes da questão, como já dito anteriormente, num processo civil embasado no estado constitucional, não parece crível admitir a solução de uma controvérsia que envolva a apuração de condutas apontadamente ímprobas com base em meras presunções de índole processual.

Sobre o tema, vale considerar as importantes lições de Michele Taruffo:

Tudo isso equivale dizer que a não contestação da alegação de um fato não tem, por si só, qualquer efeito vinculante, nem para as partes nem para o juiz: não se trata de um negócio estipulado entre as partes, mas sim de uma situação em que não se elimina o valor da verdade como condição de justiça da decisão; resulta, de qualquer modo, oportuno minimizar a eventualidade de que uma decisão seja tomada sem uma apuração efetiva da verdade dos fatos relevantes. ${ }^{43}$

De todo modo, pela leitura do art. 345, inciso II, do Código de Processo Civil, os efeitos materiais da revelia não são aplicados aos litígios que versem sobre direitos indisponíveis e, pelo conteúdo, dimensão difusa da ação de improbidade e gravidades das penalidades previstas na LIA, não há dúvidas de sua indisponibilidade e, portanto, do afastamento da presunção contida no art. 344 do CPC.

Por outro lado, também é possível concluir pela inviabilidade da presunção de veracidade decorrente da revelia nas ações de improbidade administrativa pelo previsto no "art. 17, §1º, da Lei n. 8.429/92, que veda 'a transação, acordo ou conciliação', não se devendo descurar que um dos parâmetros delineadores do conceito de 'indisponibilidade de direitos' é justamente a impossibilidade de 'composições' a seu respeito". ${ }^{44}$

Derradeiramente, outra irradiação do processo civil moderno incidente sobre as ações de improbidade administrativa encontra-se nos casos em que o estado-juiz reconheça a aplicabilidade de sanções diferentes daquelas almejadas na peça preambular, tendo em vista o princípio da adstrição entre o pedido e a sentença (CPC, arts. 141 e 492).

O STJ vem admitindo essa possibilidade, ao entender que "não infringe o princípio da congruência a decisão judicial que enquadra o ato de improbidade em dispositivo diverso do indicado na inicial, eis que deve a defesa

43 Michele Taruffo, Uma simples verdade, op. cit., p. 158.

44 Emerson Garcia e Rogério Pacheco Alves, Improbidade administrativa, op. cit., p. 1059. 
ater-se aos fatos e não à capitulação jurídica", ${ }^{45}$ desde que, é claro, presentes todos os requisitos da modalidade diversa de improbidade administrativa objeto de condenação.

No mesmo sentido, no REsp no 439.280/RS o então ministro do STJ Luiz Fux entendeu que "as multifárias ações administrativas que se enquadram no novel diploma, transmudam o pedido de adequação das mesmas, aos fatos previstos, como nítida ação fungível, podendo o juízo, ao decidir, impor sanção aliud porém minus". ${ }^{46}$

Em sentido oposto, Néviton Guedes diz que a possiblidade de alteração da capitulação jurídica pelo estado-juiz tratar-se-ia de um dogma processual a ser superado, motivo pelo qual defende a inadmissibilidade dessa modificação por entender que o acusado se defenderá da qualificação dada aos fatos, ao passo que o sancionamento imposto pelo Juízo com base em fatos e consequências jurídicas destoantes daquelas apontadas na peça preambular é antagônico à ampla defesa e contraditório. ${ }^{47}$

Idêntico entendimento foi externado pelo ministro Napoleão Nunes Maia Filho quando do julgamento do REsp no 1147564/MG ao pontuar que "o enquadramento pelo Juízo singular do ato de improbidade em dispositivo diverso do apontado na inicial, além de cercear o acusado do direito de defesa, caracteriza violação ao princípio da congruência". ${ }^{48}$

De todo modo, embora ainda seja um tema controvertido, é de todo salutar que, na hipótese de se admitir a alteração da capitulação jurídica na sentença, haja plena observância ao que dispõe os arts. 9o e 10 do NCPC (corolários do princípio da cooperação do processo civil no estado constitucional), de forma a possibilitar a plena ciência e manifestação prévia das partes a esse respeito, a fim de se evitar a surpresa, tal como defendido por Néviton Guedes:

45 BRASIL. SUPERIOR TRIBUNAL DE JUSTIÇA. Segunda Turma, REsp no 842428/ES, rela mina Eliana Calmon, DJ 21/5/2007. Disponível em: <ww2.stj.jus.br/processo/revista/ documento/mediado/?componente=ATC\&sequencial=3011651\&num_registro=200 $600688561 \&$ data $=20070521 \&$ tipo $=5 \&$ formato=PDF $>$. Acesso em: 19 out. 2017.

46 BRASIL. SUPERIOR TRIBUNAL DE JUSTIÇA. Primeira Turma, REsp no 439280/RS, rel. min. Luiz Fux, DJ 16/6/2003. Disponível em: <ww2.stj.jus.br/processo/revista/documento/me diado/?componente=ATC\&sequencial=536588\&num_registro=200200634924\&data $=20030616 \&$ tipo $=51 \&$ formato=PDF $>$. Acesso em: 19 out. 2017.

47 Néviton Guedes, Improbidade administrativa, op. cit., p. 301-302.

48 BRASIL. SUPERIOR TRIBUNAL DE JUSTIÇA. Primeira Turma, REsp no 1147564/MG, rel. min. Napoleão Nunes Maia Filho, DJe 2/9/2013. Disponível em: <ww2.stj.jus.br/processo/ revista/documento/mediado/?componente=ATC\&sequencial=29763628\&num_regi stro $=200901872717 \&$ data $=20130902 \&$ tipo $=5 \&$ formato=PDF $>$. Acesso em: 9 maio 2017. 
[...] a possibilidade efetiva e concreta da manifestação das partes sobre os fatos e sobre os fundamentos jurídicos é requisito essencial ao princípio do acesso à justiça, conformando o direito a ser ouvido pelo judiciário. Esse direito é, evidentemente, violado quando o judiciário, com surpresa para a parte, profere decisão não congruente como que foi formulado pelo autor e, nessa condição, mais grave ainda, não permitindo ao acusado, considerada a surpresa, defender-se seja do pedido, seja dos fundamentos que o suportavam. ${ }^{49}$

Assim, reforça-se que o que se debate no processo se foca nos fatos trazidos para discussão.

\section{Conclusão}

O trabalho ponderou a existência de uma nova fase metodológica do direito processual, nominando-a de "processo civil no estado constitucional", surgida em virtude da existência de fatores culturais e sociais existentes na contemporaneidade, correlacionando, assim, as irradiações desse novo modelo com as ações de improbidade administrativa.

Isso porque, não obstante a existência de divergências doutrinárias, trilhou-se pelo entendimento de que as ações de improbidade administrativa teriam natureza cível, importando, consequentemente, na aplicação do modelo processual em evidência na atualidade, aliado, é claro, às características especiais regidas pela Lei de Improbidade Administrativa.

Desse modo, foram traçadas as diretrizes inerentes ao modelo de constatação que deve ser utilizado para a apreciação dos fatos pelo estado-juiz, notadamente nas ações de improbidade administrativa, delimitando, ainda, a necessidade de clarividenciar previamente aos sujeitos processuais o critério adotado para tal mister, exatamente em virtude do princípio da cooperação e do contraditório.

Ainda, como fator consequencial da nova sistemática processual existente, foram fixadas balizas ínsitas às ações de improbidade administrativa para fins de salvaguardar um processo epistêmico. Com tal enfoque, aliás, verificou-se a necessidade de firmar novos paradigmas, inclusive em âmbito

\footnotetext{
49 Néviton Guedes, Improbidade administrativa, op. cit., p. 309.
} 
jurisprudencial, acerca de determinadas interpretações tradicionalmente cristalizadas.

Nesse desiderato, o presente estudo abordou questões próprias das ações de improbidade administrativa e os reflexos impostos pelo processo civil calcado no estado constitucional daí advenientes.

Como corolário desses reflexos, entendeu-se que a inobservância do procedimento previsto no art. $17, \S 7 \%$, da LIA, ao contrário do que prevalece jurisprudencialmente, gera nulidade absoluta; a impossibilidade de aplicação dos efeitos materiais da revelia na improbidade administrativa - apesar de existir controvérsia a esse respeito - e a necessidade de, ao menos, permitir prévia ciência e manifestação das partes antes de eventual sentença que reconheça a prática de ato ímprobo alterando a capitulação jurídica delineada na peça preambular.

Em linha conclusiva, é indene de dúvidas que a nova metodologia ínsita ao direito processual civil contemporâneo acarreta, necessariamente, a releitura de diversos institutos aplicáveis às ações de improbidade administrativa, especialmente no modelo de constatação utilizado na formação do convencimento judicial, além, é claro, da necessária observância do princípio da colaboração quanto a todos os sujeitos processuais, inclusive de forma prévia, sob pena de descaracterização da justiça calcada num processo epistêmico que visa na seara da improbidade administrativa entrelaçar a legitimidade estatal em todas as suas vertentes (probidade da administração pública e legitimidade ideológica do processo judicial).

\section{Referências}

ALVARENGA, Aristides Junqueira. Reflexões sobre improbidade administrativa no direito brasileiro. In: BUENO, Cassio Scarpinella; PORTO FILHO, Pedro Paulo de Resende (Org.). Improbidade administrativa: questões polêmicas e atuais. São Paulo: Sociedade Brasileira de Direito Público, 2001.

BRASIL. Lei $n^{o} 8.429$ de 2 de junho de 1992. Disponível em: <www.planalto.gov. br/ccivil_03/leis/L8429.htm>. Acesso em: 9 out. 2017.

SUPERIOR TRIBUNAL DE JUSTIÇA. Corte Especial, AgRg na Rcl 10.037 - MT, rel. min. Luis Felipe Salomão, DJe 25/11/2015. Disponível em: $<$ https://ww2.stj.jus.br/processo/revista/documento/mediado/?componente= 
ATC\&sequencial $=54894933 \&$ num_registro $=201202010299 \&$ data $=20151125 \&$ ti $\mathrm{po}=5 \&$ formato $=\mathrm{PDF}>$. Acesso em: 5 out. 2017.

SUPERIOR TRIBUNAL DE JUSTIÇA. Primeira Turma, REsp no 439.280/ RS, rel. min. Luiz Fux, DJ 16/6/2003. Disponível em: <ww2.stj.jus.br/processo/ revista/documento/mediado/?componente=ATC\&sequencial=536588\&num registro $=200200634924 \&$ data $=20030616 \&$ tipo $=51 \&$ formato $=P D F>$. Acesso em: 19 out. 2017.

SUPERIOR TRIBUNAL DE JUSTIÇA. Primeira Turma, REsp no 1.147.564/MG, rel. min. Napoleão Nunes Maia Filho, DJe 2/9/2013. Disponível em: <ww2.stj.jus.br/processo/revista/documento/mediado/?comp onente $=$ ATC $\&$ sequencial $=29763628 \&$ num_registro $=200901872717 \&$ data $=2013$ 0902\&tipo=5\&formato=PDF>. Acesso em: 9 maio 2017.

SUPERIOR TRIBUNAL DE JUSTIÇA. Primeira Turma, REsp n. 1.470.675/ DF, Rel. para o Acórdão Min. Sérgio Kukina, DJe 9/2/2017. Disponível em:

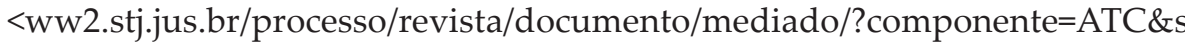
equencial $=68022110 \&$ num_registro $=201303980842 \&$ data $=20170209 \&$ tipo $=5 \& \mathrm{f}$ ormato=PDF $>$. Acesso em: 16 out. 2017.

SUPERIOR TRIBUNAL DE JUSTIÇA. Segunda Turma, EDcl no AREsp n. 57435-RN, rel ${ }^{\mathrm{a}} \min ^{\mathrm{a}}$ Eliana Calmon, DJe 9/10/2013. Disponível em: <ww2. stj.jus.br/processo/revista/documento/mediado/?componente=ATC\&sequenc ial $=31386412 \&$ num_registro $=201102260649 \&$ data $=20131009 \&$ tipo $=5 \&$ formato $=$ PDF $>$. Acesso em: 17 out. 2017.

SUPERIOR TRIBUNAL DE JUSTIÇA. Segunda Turma, Recurso Especial no 1.319.770-SP, rel. ministro Herman Benjamin, Dje 10/4/2017. Disponível em:

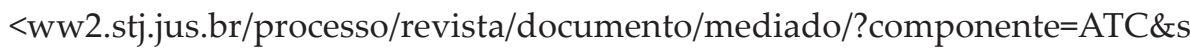
equencial $=35971972 \&$ num_registro $=201200049192 \&$ data $=20170419 \&$ tipo $=5 \& f$ ormato=PDF $>$. Acesso em: 31 ago. 2017.

SUPERIOR TRIBUNAL DE JUSTIÇA. Segunda Turma, REsp no 842.428/ ES, rele mina Eliana Calmon, DJ 21/5/2007. Disponível em: <ww2.stj.jus.br/ processo/revista/documento/mediado/?componente $=$ ATC \&sequencial $=3011$ $651 \&$ num_registro $=200600688561 \&$ data $=20070521 \&$ tipo $=5 \&$ formato $=P D F>$. Acesso em: 19 out. 2017.

SUPERIOR TRIBUNAL DE JUSTIÇA. Segunda Turma, REsp n. 1.330.058PR, rel. min. Mauro Campbell Marques, DJe 28/6/2013. Disponível em: $<$ ww2.stj.jus.br/processo/revista/documento/mediado/?componente=ATC\& 
sequencial $=29607567 \&$ num_registro $=201201286385 \&$ data $=20130628 \&$ tipo $=5 \&$ formato $=$ PDF $>$. Acesso em: 17 out. 2017.

SUPREMO TRIBUNAL FEDERAL. Pleno, Petição no 3240 AgR/DF, rel. Min. Roberto Barroso. Disponível em: <http://portal.stf.jus.br/processos/ downloadPeca.asp?id=315062116\&ext=.pdf $>$. Acesso em: 26 mar. 2019.

SUPREMO TRIBUNAL FEDERAL. Segunda Turma, RE 656.558-SP, rel. min. Dias Toffoli. Disponível em: <www.stf.jus.br/arquivo/cms/noticia NoticiaStf/anexo/RE656558DT.pdf>. Acesso em: 31 ago. 2017.

BUENO, José Antonio Pimenta. Direito publico brasileiro e analyse da Constituição do Imperio. Rio de Janeiro: Typographia Imp. e Const. de J. villeneuve \& C., 1857.

CAMBI, Eduardo. Neoconstitucionalismo e neoprocessualismo - direitos fundamentais, políticas públicas e protagonismo Judiciário. São Pauo: Ed. Almedina, 2016.

CANOTILHO, José Joaquim Gomes. Direito constitucional e teoria da constituição. 6. ed. Coimbra: Almedina, 2002.

CAPEZ, Fernando. Improbidade administrativa: limites constitucionais. 2. ed. São Paulo: Saraiva, 2015.

CARPES, Artur. O direito fundamental ao processo justo: notas sobre o modelo de constatação nos processos envolvendo as Ações de Improbidade Administratriva. In: LUCON, Paulo Henrique dos Santos; COSTA, Eduardo José da Fonseca; COSTA, Guilherme Recena (Coord.). Improbidade administrativa: aspectos processuais da Lei no 8.429/92. São Paulo: Atlas, 2004.

DIDIER JUNIOR, Fredie. Curso de direito processual civil: introdução ao direito processual civil, parte geral e processo de conhecimento. 20. ed. Salvador: Jus Podivm, 2018. v. 1.

FERRAZ, Sergio. Aspectos processuais na lei sobre improbidade administrativa. In: BUENO, Cassio Scarpinella; PORTO FILHO, Pedro Paulo de Resende (Org.). Improbidade administrativa: questões polêmicas e atuais. São Paulo: Sociedade Brasileira de Direito Público, 2001.

GARCIA, Emerson; ALVES, Rogério Pacheco. Improbidade administrativa. 9. ed. São Paulo: Saraiva, 2017.

GUEDES, Néviton. Improbidade administrativa: temas atuais e controvertidos. Coordenação do ministro Mauro Campbell. 2. tir. São Paulo: Forense, 2017. 
KNIJNIK, Danilo. A prova nos juízos cível, penal e tributário. Rio de janeiro: Forense, 2007.

MARTINS JÚNIOR, Wallace Paiva. Probidade Administrativa. 4. ed. São Paulo: Saraiva, 2009.

MITIDIERO, Daniel. Colaboração no Processo Civil: pressupostos sociais, lógicos e éticos. 3. ed. São Paulo: Revista dos Tribunais, 2015.

; MARINONI, Luiz Guilherme; ARENHART, Sérgio Cruz Arenhart. Novo curso de processo civil. Teoria do processo civil, v. 1. São Paulo: Revista dos Tribunais, 2015.

NERY JUNIOR, Nelson; ANDRADE NERY, Rosa Maria. Comentários ao Código de Processo Civil. São Paulo: Revista dos Tribunais, 2015.

NEVES, Daniel Amorim Assunção; OLIVEIRA, Rafael Carvalho Rezende. Manual de improbidade administrativa. 5. ed. rev., atual. e ampl. Rio de Janeiro: Forense; São Paulo: Método, 2017.

OLIVEIRA, Carlos Alberto Alvaro de. Do formalismo no processo civil: proposta de um formalismo-valorativo. 4. ed. rev. atual. e aum. São Paulo: Saraiva, 2010.

PAZZAGLINI FILHO, Marino. Lei de Improbidade Administrativa comentada: aspectos constitucionais, administrativos, civis, criminais, processuais e de responsabilidade fiscal, legislação e jurisprudência. 6. ed. São Paulo: Atlas, 2015.

REALE, Miguel. Filosofia do direito. 20. ed. São Paulo: Saraiva, 2012.

REMEDIO, José Antonio. Direito administrativo. 2. ed. São Paulo: Verbatim, 2015.

TARUFFO, Michele. Uma simples verdade: o juiz e a construção dos fatos. Tradução de Vitor de Paula Ramos. São Paulo: Marcial Pons, 2016.

TOJAL, Sebastião Botto de Barros; CAETANO, Flávio Crocce. Competência e prerrogativa de foro em ação civil de improbidade administrativa. In: BUENO, Cassio Scarpinella; PORTO FILHO, Pedro Paulo de Resende (Org.). Improbidade administrativa: questões polêmicas e atuais. São Paulo: Sociedade Brasileira de Direito Público, 2001.

ZAVASCKI, Teori Albino. Processo coletivo: tutela de direitos coletivos e tutela coletiva de direitos. 7. ed. São Paulo: Revista dos Tribunais, 2017. 